\title{
Science and Engineering in Antiquity
}

G IBBON, in "The Decline and Fall of the Roman Empire", when describing Rome in all its glory, said the city was "filled with amphitheatres, theatres, temples, porticoes, triumpha] arches, baths and aqueducts, all variously conducive to the health, the devotion, and the pleasures of the meanest citizen". The aqueducts appealed especially to him, and of them he wrote, "The boldness of the enterprise, the solidity of the execution, and the uses to which they were subservient, rank the aqueducts among the noblest monuments of Roman genius and power." They evidently make the same appeal to Mr. W. J. E. Binnie, who, having taken as the theme for his presidential address to the Institution of Civil Engineers, delivered on November 1, "Science and Engineering in Ancient Times", devoted many of his remarks to the work of Frontinus on the aqueducts. This subject no doubt was also a congenial one, owing to Mr. Binnie's own work as a hydraulic engineer.

Sextus Julius Frontinus, who was born about A.D. 35 and died about 106, was a very able and conscientious government servant, and for a time was governor of Great Britain. When about sixty years of age, he was appointed "Curator Aquarum" or Commissioner to the Water Supply of Rome, and this led him to write his two books, "De Aquis Urbis Romæ", an English translation of which was published in 1899, by the distinguished American hydraulic engineer, Clemens Herschel (1842-1930), himself the inventor of the Venturi meter. When Frontinus took office, there were nine aqueducts carrying water to Rome, and one of them had been in use nearly four hundred years, a longer period than Drake's leat has carried water to Plymouth. The total length of the nine aqueducts was 263 miles, about $35 \frac{1}{2}$ miles being borne on arches. The total capacity as estimated by Herschel was 84 million gallons a day, but the actual quantity supplied did not amount to more than 38 million gallons. The Appian aqueduct (313 B.c.) was sixteen miles long and was almost entirely underground; the Anio Vetus (273 в.o.) was forty miles long. The Marcia was fifty-eight miles long, and was constructed about 145 B.c. The two older aqueducts followed the contour of the ground, but in the Marcia, arches with a total length of six and a half miles carried the aqueduct across the valleys. The Claudia, the Julia, fourteen miles, the Virgo, thirteen and a half miles, the Alsietina, twenty-nine miles, and the New Anio were erected nearer the age of Frontinus, some of them indeed in his lifetime. One portion of the Claudia was a tunnel three miles long.

The three earliest aqueducts were constructed of dressed stones about 18 in. $\times 18$ in. $\times 42$ in. set in mortar, but most of the later aqueducts were of concrete and brickwork ; the arches being divided into voussoirs by brick courses. The waterways were rendered with opus signinum made of pottery ground into powder mixed with lime mortar. The durability of this lining is shown by old underground tanks and conduits in Alexandria, where the surrounding limestone has been eroded away by water, leaving the lining intact. Settling tanks were provided on each aqueduct, and water was led into buildings by lead pipes. Payment was made according to the diameter of the bronze nozzle or calix through which the water flowed.

Frontinus was aware that the quantity of water varied with the head, and the length of pipe, but the laws governing the flow of water were unknown. By-laws existed regarding the water supply, and it fell to the lot of Frontinus to enforce them.

In considering the construction of the roads, aqueducts, and tunnels of antiquity, a question naturally arises as to what methods were employed in surveying and laying down the plans. The answer to this question was given by $\mathrm{Mr}$. Binnie earlier in his address, when dealing with the writings of Hero of Alexandria.

To Hero are attributed a book on "Pneumatics", three on "Mechanics", one on "Catoptrics", and another on the "Dioptra". The "Pneumatics" has been published in English, and the other five have been translated by Mr. R. C. S. Walters, a member of the Institution of Civil Engineers, and Mr. Binnie had had the advantage of perusing his manuscripts. In this connexion, it is perhaps worth recalling that in $1921 \mathrm{Mr}$. Walters read a paper to the Newcomen Society entitled, "Greek and Roman Engineering Instruments", and that in 1928 the University of Washington, Seattle, U.S.A., published Mr. E. N. Stone's pamphlet on "Roman Surveying Instruments". For lengths, the Romans used the Pertica, the Decempeda, and also the Hodometer, or road-measurer; for horizontal angles they used the Groma, an example of which was unearthed at Pompeii in 1912, while by means of the Dioptra they could measure both horizontal and vertical angles. The Dioptra was the forerunner of our theodolite, and with it, said 
Mr. Binnie, very accurate levelling could be carried out and it was possible to set out aqueducts with very flat gradients.

Besides the writings of Hero and Frontinus, Mr. Binnie touched upon the work of the Egyptians and their methods of drilling granite; the views of Lucretius on matter, the universe and time; the career of Archimedes; and finally and briefly, the work of that versatile genius Leonardo da Vinci, a review of whose many activities was given by Mr. E. McCurdy to the Royal Institution on March 19, 1920, a full report appearing in NATURE of May 6 and 13 ; and by Mr. J. W. Lieb in a paper read to the Franklin Institute in 1921.

\section{Obituary Notice}

\section{Prof. Karl Sudhoff}

$\mathrm{W}$ regret to announce the death of Karl Sudhoff, the Nestor and doyen of medical historians, which took place at Salzwedel in Saxony on October 8 at the ripe age of eighty-four years.

Sudhoff was born on November 26, 1853, the son of a theologian and philosopher, at Frankfort-on-Main, the birthplace of Goethe, who formed the subject of many of his non-medical writings. He qualified at Erlangen in 1875 with a thesis on a subject-primary multiple carcinoma of the osseous system-which gave no indication of his future activities, and for the next thirty years remained in general practice with a leaning towards gynæcology, first at Bergen near Frankfort and afterwards at Hochdahl near Düsseldorf. $\mathrm{He}$ soon rose to eminence in his profession, and his financial success enabled him to accumulate a library rich in medico-historical works.

During this time, Sudhoff won a considerable reputation by his studies on Paracelsus, so that he was elected the first president of the German Society of the History of Medicine, founded in 1901. Four years later he was appointed as the first occupant of the chair of the history of medicine at Leipzig, where he founded an institute for this speciality, and held this post until 1924, being succeeded by his brilliant pupil, Dr. Henry E. Sigerist, now professor of the history of medicine at Johns Hopkins University.

Sudhoff's activities may be considered under three headings : (1) his successful career as a medical practitioner, in acknowledgment of which he was created a councillor in 1900 ; (2) his epoch-making work as a medical historian; (3) his ability as an organizer. Sudhoff was an extraordinarily prolific writer, as is shown by the fact that a bibliography of his works and those of his pupils occupied nearly thirty pages of the Festschrift dedicated to him in 1924 on the occasion of his seventieth birthday, and more than fifty pages of his Archiv published ten years later. His chief works, in chronological order, were his studies of Paracelsus, the iatro-mathematicians of the fifteenth and sixteenth centuries, the anatomy of the Middle Ages, the history of hygiene, German medical incunabula, Alexandrian medicine, ancient balneology, manuscript plague tracts, the early history of syphilis, the school of Salerno, the surgery of the Middle Ages, the history of dentistry, a survey of the history of medicine, and early writers on paediatrics. His minor works included obituaries of medical historians and others, an autobiographical sketch entitled "Aus muiner Arbeit", and numerous reviews of current litэrature on the history of medicine. In addition to purely medical subjects, he wrote on folk-lore, magic, alchemy, astrology and Goethe in relation to the Rhineland.

Mention should also be made of his editorial work. In 1908 Sudhoff founded the Archiv für die Geschichte der Medizin und der Naturwissenschaften, to which his name became attached in 1929; in 1909 he became editor of Klassiker der Medizin, and he was also joint editor of several other medico-historical publications.

The organizing ability of Sudhoff was shown by his establishment of the Institute for the History of Medicine at Leipzig, which he made a model of its kind, the organization of the Goethe exhibition in 1899 on the occasion of the hundred and fiftieth anniversary of the poet's birth, the active part which he took in the preparation of a historical section in the German exhibition of hygiene at Dresden in 1911, and his activity as dean of the medical faculty at Leipzig in 1922-23.

Sudhoff had many friends in Great Britain, to which he paid several visits both before and after the Great War. His Festschrift was dedicated to him by Sir Clifford Allbutt, and several other British writers contributed to the volume. He was elected a corresponding member of the Section of the History of Medicine of the Royal Society of Medicine in 1913, the year of the International Congress of Medicine held in London, when he read a paper at the historical section of the Congress on the origin of syphilis, and thirteen years later he was elected an honorary fellow of the Royal Society of Medieine.

J. D. R.

WE regret to announce the following deaths:

Sir John Griffith, president of the Institution of Civil Engineers in 1919, on October 21, aged ninety years.

Mr. George Jennison, formerly owner and principal curator of the Belle Vue Zoological Gardens, Manchester, on October 21, aged sixty-six years.

Colonel J. Clibborn, C.I.E., formerly principal of the Thomason Engineering College, Rorkee, known for his work in connexion with irrigation in Northern India, on October 31, aged ninety years. 